\title{
BEBERAPA CATATAN TENTANG ASAS DEMI KEADILAN BERDASARKAN KETUHANAN YANG MAHA ESA
}

\author{
Ahkam Jayadi \\ Universitas Islam Negeri (UIN) Alauddin Makassar \\ Email: ahkamjayadi@gmail.com
}

\section{Abstract}

Jurisdiction in Indonesia executed pursuant to principle, " For The Shake of Justice Pursuant to Believing in One God". How to comprehend and realize in reality of the principle do not be found its clarification. Various other law and regulation which represent regulation of execution of judicial power law arranging about jurisdiction institutes. Executor of judgement paintbrush do not also arrange furthermore about this jurisdiction principle. the Regulation cause judges do not have the understanding of same about ground or principle. As a result applying of the principle only comprehended in general that handled case it have to earn to be justified do not only to State, society however also which do not less important is to God Which Single The most as target of top everything. Therefore, require to be made a change to law and regulation about judgement paintbrush.

Key Word : Jurisdiction, God Who Are Single The most, Justice

\begin{abstract}
Abstrak
Peradilan di Indonesia dilaksanakan berdasarkan prinsip, "Demi Keadilan Berdasarkan Ketuhanan Yang Maha Esa". Bagaimana memahami dan mewujudkan di dalam realitas dari prinsip tersebut tidak ditemukan penjelasannya. Berbagai peraturan perundang-undangan lainnya yang merupakan peraturan pelaksanaan dari undang-undang kekuasaan kehakiman yang mengatur tentang lembaga-lembaga peradilan. Pelaksana kekuasan kehakiman tidak juga mengatur lebih lanjut tentang prinsip peradilan ini. Ketidakjelasan peraturan tersebut menyebabkan hakim-hakim tidak memiliki pemahaman yang sama tentang prinsip atau asas tersebut. Akibatnya penerapan prinsip tersebut hanya dipahami secara umum bahwa perkara yang ditanganinya harus dapat dipertanggungjawabkan tidak hanya kepada Negara, masyarakat akan tetapi juga yang tidak kalah pentingnya adalah kepada Tuhan Yang Maha Esa sebagai tujuan puncak segala sesuatu. Oleh karena itu, perlu dilakukan perubahan terhadap peraturan perundang-undangan tentang kekuasan kehakiman.
\end{abstract}

Kata Kunci : Peradilan, Tuhan Yang Maha Esa, Keadilan

Jurisprudentie | Volume 5 Nomor 1 Juni 2018 


\section{PENDAHULUAN}

Tndonesia adalah negara hukum sebagaimana ditegaskan di dalam Undang Undang Dasar Negara Republik Indonesia Tahun 1945 (Pasal 1 ayat 3).

Indonesia sebagai negara hukum lebih lanjut didukung dengan terbentuknya kelembagaan negara, yaitu: lembaga legislatif (Dewan Perawakilan Rakyat), lembaga eksekutif (Pemerintah dalam arti sempit dan dalam arti luas) serta lembaga yudikatf (Mahkamah Agung dan lembaga-lembaga peradilan yang ada di bawahnya serta badan-badan peradilan lainnya). Tentu saja penegasan UUD 1945 tersebut tidak sekedar ditempatkan sebagai pengakuan UUD 1945 semata, akan tetapi yang lebih utama adalah sejauh mana hal tersebut di implementasikan di dalam realitas kehidupan bermasyarakat, berbangsa dan bernegara sebagaimana tugas dan fungsinya masing-masing.

Perlawanan terhadap berbagai bentuk pelanggaran hukum seiring dengan kejadian yang melanda berbagai lembaga negara kita belakang ini haruslah menjadi gerakan massif. Betapa tidak berbagai tindakan melawan hukum telah masuk ke jajaran Pemerintah, Komisi Pemilihan Umum, Dewan Perwakilan Rakyat, Komisi Pemberantasan Korupsi, Mahkamah Konstitusi, Mahkamah Agung dan berbagai tingkatan peradilan yang ada dibawahnya ${ }^{1}$. Kejadian tersebut diprediksi sebagai efek langsung dari ketidak mampuan peraturan perundangundangan yang ada sebagai alat pengendali perilaku sosial masyarakat. Demikian juga kegagalan masyarakat untuk mensinergikan tingkat pemahaman hukum dan kesadaran hukumnya dengan muatan berbagai peraturan perundang-undangan yang ada untuk mewujudkan keadilan, kemanfaatan dan kepastian hukum serta kultur masyarakat Indonesia yang tidak mendukung.

Pembukaan Undang Undang Dasar Negara Republik Indonesia Tahun 1945 (UUD 1945) telah menegaskan bahwa: "Atas berkat Rahmat Allah Yang Maha Kuasa dan dengan didorongkan oleh keinginan luhur, supaya berkehidupan kebangsaan yang bebas, maka rakyat Indonesia menyatakan dengan ini kemerdekaannya". Penegasan Pembukaan UUD 1945 tersebut di pertegas di dalam Pasal 29 ayat (1) Negara berdasar atas Ketuhanan Yang Maha Esa ${ }^{2}$. UU No. 48 Tahun 2009 tentang Kekuasaan Kehakiman pada Pasal 2 ayat (1) Peradilan dilakukan, "Demi Keadilan Berdasarkan Ketuhanan Yang Maha Esa".

${ }^{1}$ Ingat berbagai kasus mafia peradilan yang menyertai kasus KPU dengan MK, Bank Century, Kasus pajak Gayus Tambunan serta korupsi oleh Nasaruddin.

${ }^{2}$ Lihat lebih lanjut hasil empat kali amandemen UUD 1945 beserta perdebatan yang melingkupinya. 
Dalam kaitan dengan pasal tersebut di atas maka kita harus memahami dan berpegang teguh pada pemahaman bahwa: Indonesia meskipun bukan negara agama atau negara yang menjadikan salah satu agama sebagai agama resmi negara, akan tetapi Indonesia adalah negara yang menghormati nilai-nilai agama sebagai sumber nilai atau sumber hukum kehidupan ${ }^{3}$. Agama di Indonesia memiliki posisi dan kedudukan yang sangat penting dan strategis tidak hanya dalam kehidupan bermasyarakat akan tetapi juga di dalam kehidupan berbangsa dan bernegara oleh karena ajaran agama tidak hanya untuk ruang lingkup kehidupan duniawi semata akan tetapi juga untuk kehidupan akhirat.

Dari sisi legislasi dan penegakan hukum, yang berperan penting di dalam proses tersebut adalah manusia yang terlibat di dalamnya, termasuk manusia yang menjadi penegak hukum ${ }^{4}$. Bila manusia yang ada dibalik proses-proses tersebut sangat penting posisi dan kedudukannya, maka tentu saja nilai-nilai agama juga menjadi penting adanya. Betapa tidak ruang lingkup nilai-nilai agama adalah mengatur manusia yang ada di balik proses tersebut ${ }^{5}$. Satjipto Rahardjo mengingatkan bahwa: pengamatan terhadap berlakunya hukum secara lengkap ternyata melibatkan berbagai unsur sebagai berikut: 1. Peraturan sendiri, 2. Warga negara sebagai sasaran pengaturan, 3. Aktivitas birokrasi pelaksana, 4. Kerangka sosial politik, ekonomi, budaya yang ada yang turut menentukan bagaimana setiap unsur dalam hukum tersebut di atas menjalankan apa yang menjadi bagiannya ${ }^{6}$. Selanjutnya Soerjono Soekanto menambahkan bahwa: Secara sederhana dapat

${ }^{3}$ Diingatkan oleh Satjipto Rahardjo bahwa: Hukum modern sangat bersandar pada "legalitas formal" dan "birokrasi" dalam cara mengaturnya, suatu hal yang memang tak dapat dihindari dalam keadaan masyarakat modern yang kompleks ini. Pokoknya hukum menjadi semakin jauh dari konteks rasa keadilan, moralitas dan lain-lain segi kerokhanian manusia, Permasalahan Hukum di Indonesia, (Bandung: Alumni, 1983), h. 96.

${ }^{4}$ Lihat Soerjono Soekanto, Pokok-pokok Sosiologi Hukum, (Jakarta: PT. Raja Grafindo, 1997), h. 3 bahwa: Hukum secara sosiologis adalah penting dan merupakan suatu lembaga kemasyarakatan (social institution) yang merupakan himpunan nilai-nilai, kaidah-kaidah dan polapola perikelakuan yang berkisar pada kebutuhan-kebutuhan pokok manusia. Hukum sebagai suatu lembaga kemasyarakatan, hidup berdampingan dengan lembaga-lembaga kemasyarakatan lainnya dan saling pengaruh mempengaruhi dengan lembaga-lembaga kemasyarakatan tadi.

${ }^{5}$ Soerjono Sokenato menyatakan bahwa: pengaruh hukum terhadap sikap tindak atau perilaku yang dihasilkan dapat diklasifikasi sebagai: ketaatan (compliance), ketidak taatan atau penyimpangan (deviance), dan pengelakan (evorian), Efektivikasi Hukum dan Peranan Sanksi, (Bandung: CV. Remadja Karya, 1985), h. 6. 13.

${ }^{6}$ Satjipto Rahardjo, Permasalahan Hukum di Indonesia, (Bandung: Alumni, 1987), h. 
dikatakan, bahwa seseorang taat apabila ia bersikap tindak atau berprilaku sesuai dengan harapan pembentuk hukum, sebagaimana dipahaminya ${ }^{7}$.

Hukum itu tentu saja dibuat dan diberlakukan untuk kemaslahatan manusia melalui pencapaian tujuan hukum. Hukum untuk manusia bukan sebaliknya manusia untuk hukum. Meskipun sebuah peraturan hukum lahir dan ditetapkan dari atas melalui lembaga negara yang diberi kewenangan untuk itu (seperti lembaga legislatif pusat maupun daerah), akan tetapi proses pembuatannya tentu saja harus didahului dengan penelitian tentang hal tersebut di tengah masyarakat (yang dikenal dalam kajian teori hukum, "sumber hukum materil") dengan melibatkan semua elemen masyarakat ${ }^{8}$. Untuk itu pada ranah inilah perlu pelibatan nilai-nilai spiritualitas agama (Islam) dan nilai-nilai hukum adat dalam setiap penyusunan rancangan undang-undang, rancangan peraturan daerah dan peraturan perundang-undangan lainnya. Secara sosiologis dalam kehidupan bermasyarakat, agama (Islam) adalah salah satu "institusi pengendalian sosial" di samping institusi-institusi pengendalian sosial lainnya ${ }^{9}$. Pada ranah inilah mestinya kita memaknai prinsip peradilan tersebut.

\section{PEMBAHASAN}

\section{A. Proses Pemeriksaan Perkara}

Penjelasan umum Undang Undang No. 49 Tahun 2009 tentang Peradilan Umum menegaskan bahwa: Di Negara Republik Indonesia sebagai negara hukum yang berdasarkan Pancasila dan Undang Undang Dasar 1945. Keadilan, kepastian hukum, dan ketertiban penyelenggaraan sistem hukum merupakan hal-hal pokok untuk menjamin kehidupan masyarakat, berbangsa dan bernegara. Hal pokok tersebut merupakan masalah yang sangat penting dalam usaha mewujudkan suasana perikehidupan yang sejahtera, aman, tenteram, dan tertib seperti yang diamanatkan oleh peraturan perundang-undangan yang ada. Oleh karena itu untuk mewujudkannya dibutuhkan adanya lembaga yang bertugas menyelenggarakan keadilan dengan baik. Salah satu lembaga untuk menegakkan kebenaran dalam mencapai keadilan, ketertiban, dan kepastian hukum adalah badan-badan peradilan. Badan-badan peradilan sebagaimana dimaksudkan Undang Undang

${ }^{7}$ Soerjono Soekanto, Efektivikasi Hukum dan Peranan Sanksi, h. 5.

${ }^{8}$ Hal ini dimungkinkan dengan berlakunya UU No. 12 Tahun 2011 Tentang Pembentukan Peraturan Perundang-Undangan.

${ }^{9}$ Setiap masyarakat memerlukan suatu mekanisme pengendalian sosial agar segala sesuatunya berjalan dengan tertib (Joseph G. Roucek, Social Control, (London: Duan Nestrand Company, Inc, 1951), h. 60. 
Nomor 14 Tahun 1970 tentang Ketentuan-ketentuan Pokok Kekuasaan Kehakiman. Undang-undang ini kemudian diperbaharui dengan Undang Undang Nomor 4 Tahun 2004 dan terakhir dirubah dengan Undang Undang No. 48 Tahun 2009, yang masing-masing mempunyai lingkup kewenangan dan wilayah yurisdiksi dalam mengadili perkara atau sengketa di bidang tertentu.

Upaya mewujudkan peradilan yang sederhana, cepat, tepat, adil dan dengan biaya ringan, tentu saja bukan pekerjaan mudah ${ }^{10}$. Kekuasaan kehakiman di lingkungan peradilan umum dalam undang-undang ini dilaksanakan oleh Pengadilan Negeri dan Pengadilan Tinggi. Kedua tingkatan peradilan tersebut berpuncak pada Mahkamah Agung, sesuai dengan prinsip-prinsip yang ditentukan dalam peraturan perundang-undangan yang mengatur tentang peradilan. Tentang susunan, kekuasaan dan kedudukan hakim serta tata kerja administrasi pada Pengadilan Negeri dan Pengadilan Tinggi diatur di dalam Undang Undang Nomor 2 Tahun 1986, undang-undang ini kemudian direvisi dengan Undang Undang No. 8 Tahun 2004 dan terakhir dengan Undang Undang No. 49 Tahun 2009 tentang Peradilan Umum.

Pengadilan Negeri merupakan pengadilan tingkat pertama. Tingkatan peradilan ini untuk memeriksa, memutus, dan menyelesaikan perkara pidana dan perdata bagi rakyat pencari keadilan pada umumnya, kecuali undang-undang menentukan lain. Pengadilan Tinggi merupakan pengadilan tingkat banding terhadap perkara-perkara yang diputus oleh Pengadilan Negeri. Pengadilan Tinggi juga merupakan pengadilan tingkat pertama dan terakhir mengenai sengketa kewenangan mengadili antar pengadilan negeri di daerah hukumnya.

Secara umum berikut akan diuraikan proses pemeriksaan perkara di lembaga peradilan:

\section{Tahapan Pemeriksaan Perkara di Pengadilan Agama}

Langkah awal yang dilakukan adalah, pihak (penggugat atau pemohon) yang memiliki masalah hukum mendaftarkan gugatan atau permohonannya di kepaniteraan Pengadilan Agama disertai dengan sejumlah pembayaran untuk pendaftaran gugatan atau permohonan. Selanjutnya tinggal menunggu berita atau panggilan untuk sidang yang disampaikan oleh petugas juru sita atau juru sita pengganti. Pemanggilan atau pemberitahuan tersebut dilakukan atau disampaikan

${ }^{10}$ Dalam Undang Undang Kekuasaan Kehakiman No. 48 Tahun 2009 dijelaskan bahwa: Pasal 2Ayat (4) Yang dimaksud dengan "sederhana" adalah pemeriksaan dan penyelesaian perkara dilakukan dengan cara efesien dan efektif. Yang dimaksud dengan "biaya ringan" adalah biaya perkara yang dapat dijangkau oleh masyarakat. Namun demikian, asas sederhana, cepat, dan biaya ringan dalam pemeriksaan dan penyelesaian perkara di pengadilan tidak mengesampingkan ketelitian dan kecermatan dalam mencari kebenaran dan keadilan. 
kepada pihak penggugat atau pemohon sekurang-kurangnya tiga (3) hari sebelum hari persidangan. Jika pada saat pemanggilan para pihak tidak ditemukan di alamatnya, maka surat panggilan disampaikan melalui Kepala Desa atau Lurah dimana para pihak bertempat tinggal. Mendahului proses pemanggilan itu setelah gugatan atau permohonan didaftarkan maka Ketua Pengadilan segera menetapkan Hakim atau Majelis Hakim yang akan memeriksa kasus tesebut termasuk jadwal persidangannya.

Sesuai dengan jadwal persidangan, jika para pihak datang memenuhi panggilan, maka upaya awal yang dilakukan oleh Hakim atau majelis hakim adalah upaya perdamaian. Pada perkara perceraian, seperti cerai gugat dan cerai talak, hakim wajib mendamaikan kedua belah pihak yang berperkara pada setiap kali persidangan (Pasal 56 ayat 2, Pasal 68, Pasal 82 dan Pasal 83 UU No. 7 Tahun 1989). Selanjutnya jika kedua belah pihak hadir dipersidangan maka dilanjutkan dengan mediasi (berdasarkan PERMA No. 1 Tahun 2008). Kedua belah pihak bebas memilih Hakim mediator yang tersedia di Pengadilan Agama tanpa dipungut biaya. Apabia terjadi perdamaian, maka perkaranya dicabut oleh penggugat/pemohon dan perkara telah selesai.

Pada perkara perdata pada umumnya setiap permulaan sidang, sebelum pemeriksaan perkara, hakim diwajibkan mengusahakan perdamaian antara para pihak berperkara (Pasal 154 R.Bg), dan jika tidak damai dilanjutkan dengan mediasi. Dalam mediasi ini para pihak boleh menggunakan hakim mediator yang tersedia di Pengadilan tanpa dipungut biaya, kecuali para pihak menggunakan mediator dari luar yang sudah punya sertifikat, maka biayanya seluruhnya ditanggung kedua belah pihak berdasarkan kesepakatan mereka. Apabila terjadi damai, maka dibuatkan akta perdamaian. Akta Perdamaian ini mempunyai kekuatan hukum yang sama dengan putusan hakim dan dapat dieksekusi, tetapi tidak dapat dimintakan banding, kasasi dan peninjauan kembali. Apabila tidak terjadi damai dalam mediasi, baik perkara perceraian maupun perkara perdata umum, maka proses pemeriksaan perkara dilanjutkan dengan pembacaan surat gugatan atau surat permohonan.

Sebelum surat gugatan atau surat permohonan dibacakan, jika perkara perceraian, hakim wajib menyatakan sidang tertutup untuk umum, sementara perkara perdata umum sidangnya selalu terbuka untuk umum. Surat gugatan atau permohonan yang diajukan ke Pengadilan Agama itu dibacakan oleh penggugat sendiri atau salah seorang majelis hakim, dan sebelum diberikan kesempatan oleh majelis hakim kepada tergugat atau termohon untuk memberikan tanggapan/jawabannya, pihak penggugata atau pemohon punya hak untuk mengubah, mencabut atau mempertahankan isi surat gugatan atau surat 
permohonan tersebut. Apabila penggugat menyatakan tetap tidak ada perubahan dan tambahan dalam gugatannya itu kemudian persidangan dilanjutkan ketahap berikutnya yaitu jawab menjawab antara penggugat dengan tergugat atau pemohon dengan termohon.

Setelah gugatan dibacakan, kemudian tergugat diberi kesempatan mengajukan jawabannya, baik ketika sidang hari itu juga atau sidang berikutnya. Jawaban tergugat dapat dilakukan secara tertulis atau lisan (Pasal 158 ayat 1 R.Bg). Pada tahap jawaban ini, tergugat dapat pula mengajukan eksepsi (tangkisan) atau rekonvensi (gugatan balik) dan pihak tergugat tidak perlu membayar panjar biaya perkara.

Setelah tergugat menyampaikan jawabannya, kemudian si penggugat diberi kesempatan untuk menanggapinya sesuai dengan pendapat penggugat. Pada tahap ini mungkin penggugat tetap mempertahankan gugatannya atau bisa pula merubah dengan membenarkan jawaban atau bantahan tergugat. Setelah penggugat menyampaikan repliknya, kemudian tergugat diberi kesempatan untuk menanggapinya/menyampaikan dupliknya. Dalam tahap ini dapat diulang-ulangi sampai ada titik temu antara penggugat dengan tergugat. Apabila acara jawab menjawab dianggap cukup oleh hakim, dan masih ada hal-hal yang tidak disepakati oleh kedua belah pihak, maka hal ini dilanjutkan dengan acara pembuktian.

Pada tahap ini penggugat dan tergugat diberi kesempatan yang sama untuk mengajukan bukti-bukti, baik berupa bukti surat maupun saksi-saksi secara bergantian yang diatur oleh hakim. Pada tahap selanjutnya, kesimpulan para pihak. Pada tahap ini, baik penggugat maupun tergugat diberi kesempatan yang sama untuk mengajukan pendapat akhir yang merupakan kesimpulan hasil pemeriksaan selama sidang berlangsung menurut pandangan masing-masing. Kesimpulan yang disampaikan ini dapat berupa lisan dan dapat pula secara tertulis. Selanjutnya majelis hakim melakukan musyawarah untuk menjatuhkan putusan.

Rapat permusyawaratan majelis hakim bersifat rahasia (Pasal 19 ayat 3 UU No. 4 Tahun 2004). Dalam rapat permusyawaratan majelis hakim, semua hakim menyampaikan pertimbangannya atau pendapatnya baik secara lisan maupun tertulis. Jika terdapat perbedaan pendapat, maka diambil suara terbanyak, dan pendapat yang berbeda tersebut dapat dimuat dalam putusan (dissenting opinon). Setelah selesai musyawarah majelis hakim, sesuai dengan jadwal sidang, pada tahap ini dibacakan putusan majelis hakim. Setelah dibacakan putusan tersebut, penggugat dan tergugat berhak mengajukan upaya hukum banding dalam tenggang waktu 14 hari setelah putusan diucapkan. Apabila penggugat/tergugat 
tidak hadir saat dibacakan putusan, maka Juru Sita Pengadilan Agama akan menyampaikan isi/amar putusan itu kepada pihak yang tidak hadir, dan putusan baru berkekuatan hukum tetap setelah 14 hari amar putusan diterima oleh pihak yang tidak hadir itu.

\section{Pemeriksaan Perkara Perdata di Pengadilan Negeri}

Prosedur pemeriksaan perkara perdata di Pengadilan Negeri tidak jauh berbeda dengan proses yang terjadi di Pengadilan Agama sebagaimana diuraikan di atas. Pada tahap awal penggugat memasukkan surat gugatan ke Pengadilan Negeri yang berwenang. Pada Pasal 118 HIR ditetapkan bahwa Pengadilan Negeri yang berwenang untuk memeriksa perkara adalah, Pengadilan Negeri tempat domisili tergugat. Apabila tergugat lebih dari satu, maka gugatan dimasukkan ke Pengadilan Negeri tempat domisili salah seorang tergugat. Apabila alamat tergugat tidak diketahui maka gugatan dimasukkan ke Pengadilan Negeri tempat tinggal penggugat, atau gugatan dimasukkan ke Pengadilan Negeri yang telah disepakati para pihak.

Selanjutnya dalam proses persidangan berbagai kemungkinan bisa terjadi yaitu: penggugat hadir, tergugat tidak hadir. Dalam HIR Pasal 125 ayat (1), jikalau si tergugat, walaupun dipanggil dengan patut tetap tidak datang menghadap Pengadilan Negeri pada hari yang telah ditentukan itu, dan tidak juga menyuruh seorang lain menghadap selaku wakilnya, maka tuntutan itu diterima dengan keputusan tak hadir (verstek)kecuali jika tuntutan itu melawan hak atau tidak beralasan.

Bila penggugat tidak hadir sedangkan tergugat hadir, maka HIR Pasal 124 menyatakan jikalau penggugat, walaupun dipanggil dengan patut, tidak menghadap Pengadilan Negeri pada hari yang telah ditentukan itu, dan tidak juga menyuruh seseorang lain menghadap selaku wakilnya, maka tuntutannya dipandang gugur dan si penggugat dihukum membayar biaya perkara, akan tetapi masih punya hak sesudah membayar biaya tersebut memasukkan tuntutannya sekali lagi. Sedangkan bila kedua belah pihak tidak hadir, maka demi kewibawaan badan peradilan serta agar jangan sampai ada perkara yang berlarut-larut dan tidak ada penyelesaian, maka dalam hal ini gugatan harus dicoret dari daftar perkara dan dianggap tidak pernah ada. Bila kedua belah pihak hadir, maka sidang pertama dapat dimulai dengan sebelumnya hakim menganjurkan perdamaian kepada kedua pihak, jika tidak tercapai perdamaian maka sidang dilanjutkan degan pemeriksaan lanjutan termasuk pembuktian-pembuktian.

Dalam pemeriksaan perkara perdata di Pengadilan Negeri hakim memiliki hak-hak dan kewajiban. Pada HIR Pasal 119, Ketua pengadilan negeri berkuasa 
memberi nasehat dan pertolongan kepada penggugat atau wakilnya tentang hal memasukkan surat gugatannya. Pada HIR Pasal 132, Ketua berhak pada waktu memeriksa, memberi penerangan kepada kedua belah pihak dan akan menunjukan supaya hukum dan keterangan yang mereka dapat, dipergunakan jika ia menganggap perlu supaya perkara berjalan dengan baik dan teratur. HIR Pasal 159 ayat (4), Hakim berwenang untuk menolak permohonan penundaan sidang dari para pihak, kalau ia beranggapan bahwa hal tersebut tidak diperlukan. HIR Pasal 180 ayat (1) Ketua pengadilan negeri dapat memerintahkan supaya suatu keputusan dijalankan terlebih dahulu walaupun ada perlawanan atau bandingnya, apabila ada surat yang sah, suatu tulisan yang menurut aturan yang berlaku yang dapat diterima sebagai bukti atau jika ada hukuman lebih dahulu dengan keputusan yang sudah mendapat kekuatan hukum yang pasti, demikian juga dikabulkan tuntutan dahulu, terlebih lagi di dalam perselisihan tersebut terdapat hak kepemilikan. Pada ayat (2), Akan tetapi dalam hal menjalankan terlebih dahulu ini, tidak dapat menyebabkan seseorang dapat ditahan.

Tentang kewajiban hakim dalam hal pembuktian, pada HIR Pasal 172, Dalam hal menimbang harga kesaksian, hakim harus menumbuhkan perhatian sepenuhnya tentang permufakatan dari saksi-saksi, cocoknya kesaksian yang diketahui dari tempat lain tentang perkara yang diperselisihkan, tentang sebabsebab yang mungkin ada pada saksi itu untuk menerangkan duduk perkara dengan cara begini atau begitu, tentang perkelakuan adat dan kedudukan saksi, dan pada umumnya segala hal yang dapat menyebabkan saksi-saksi itu dapat dipercaya benar atau tidak. Pada HIR Pasal 176, Tiap-tiap pengakuan harus diterima segenapnya, dan hakim tidak bebas untuk menerima sebagian dan menolak sebagian lagi, sehingga merugikan orang yang mengakui itu, keculi orang yang berutang itu dengan maksud akan melepaskan dirinya, menyebutkan perkara yang terbuktidengan kenyataan yang dusta.

Tanggun-jawab hakim dalam pemeriksaan perkara di muka pengadilan, pada HIR Pasal 372 ditegaskan bahwa, Ketua-ketua majelis pengadilan diwajibkan memimpin pemeriksaan dalam persidangan dan permusyawaratan. Pada ayat (2), Dipikulkan juga pada mereka kewajiban untuk memelihara ketertiban baik dalam persidangan, segala sesuatu yang diperintahkan untuk keperluan itu, harus dilakukan dengan segera dan seksama. Bahkan secara lebih limitatif di dalam UU No. 14Tahun 1970 pada Pasal 2 ayat (1) ditegaskan bahwa, Tugas pokok daripada hakim adalah menerima, memeriksa dan mengadili serta menyelesaikan setiap perkara yang diajukan kepadanya. Pada Pasal 5 ayat (2), Dalam perkara perdata hakim harus membantu para pencari keadilan dan berusaha sekeras-kerasnya mengatasi segala hambatan dan rintangan untuk dapat 
tercapainya peradilan yang sederhana, cepat dan biaya ringan. Pada Pasal 14 ayat (1), Hakim tidak boleh menolak untuk memeriksa dan mengadili sesuatu perkara dengan dalih bahwa hukum tidak ada atau kurang jelas, melainkan ia wajib untuk memeriksa dan mengadilinya.

Dalam hal menjatuhkan putusan diatur di dalam HIR Pasal 178 ayat (1), Hakim karena jabatannya, pada waktu bermusyawarah wajib mencukupkan segala alasan hukum, yang tidak dikemukakan oleh kedua belah pihak. Pada ayat (2) Hakim wajib mengadili atas seluruh bagian gugatan. Pada ayat (3) Ia tidak diijinkan menjatuhkan keputusan atas perkara yang tidak digugat, atau memberikan lebih dari yang digugat.

Terhadap putusan yang telah dijatuhkan oleh Hakim atau Majelis Hakim para pihak diberikan hak untu menolak atau tidak menerima putusan tersebut dengan menggunakan upaya hukum perlawanan. Upaya hukum perlawanan ada yang disebut upaya hukum biasa dan ada upaya hukum luar biasa. Upaya hukum biasa adalah perlawanan terhadap putusan hakim yang belum memperoleh kekuatan hukum tetap, sedangkan upaya hukum luar biasa adalah perlawanan yang dilakukan terhadap putusan yang telah mempunyai kekuatan hukum tetap. Upaya hukum biasa antara lain: banding(pengajuan perkara kepada pengadilan tinggi untuk dimintakan pemeriksaan ulang) dan Kasasi (yaitu pengajuan perkara ke Mahkamah Agung berupa tindakan Mahkamah Agung untuk menegakkan dan membetulkan hukum yang keliru di dalam penerapan hakim yang memeriksanya pada tingkat Pengadilan Tinggi). Upaya hukum luar biasa yatu: peninjauan kembali (yaitu, peninjauan keputusan pengadilan yang telah mempunyai kekuatan hukum tetap dengan syarat terdapat hal-hal atau keadaan yang ditentukan undangundang seperti dtemukan bukti baru).

\section{Pemeriksaan perkara pidana}

Perkara pidana di awali dengan penyelidikan serta penyidikan oleh kepolisian. Penyelidikan adalah serangkaian tindakan penyelidik untuk mencari dan menemukan suatu peristiwa yang diduga sebagai tindak pidana guna menentukan dapat atau tidaknya dilakukan penyidikan menurut cara yang diatur di dalam Undang-undang Nomor 26 tahun 2000 tentang Pengadilan Hak Asasi Manusia, Pasal 1 angka (5) bahwa, Penyelidik karena kewajibannya mempunyai wewenang menerima laporan, mencari keterangan dan barang bukti, menyuruh berhenti orang yang dicurigai dan menanyakan serta memeriksa tanda pengenal diri, dan mengadakan tindakan lain menurut hukum yang bertanggung jawab. Berdasarkan ketentuan Pasal 16 ayat (1) KUHAP, untuk kepentingan penyelidikan, penyelidik atas perintah penyidik dapat melakukan penangkapan. 
Namun untuk menjamin hak-hak asasi tersangka, perintah penangkapan tersebut harus didasarkan pada bukti permulaan yang cukup. Meskipun demikian penyelidikan yang dilakukan penyelidik tetap harus menghormati asas praduga tak bersalah (presumption of innocence). Penerapan asas ini adalah untuk melindungi kepentingan hukum dan hak-hak tersangka dari kesewenangwenangan kekuasaan para aparat penegak hukum.

Penyidikan untuk mengungkap suatu tindak pidana, maka penyidik karena kewajibannya mempunyai wewenang sebagaimana yang tercantum di dalam Pasal 7 ayat (1) KUHAP jo. Pasal 16 ayat (1) UU No. 2 Tahn 2002 tentang Kepolisian, yang menyebutkan bahwa wewenang penyidik adalah: 1). Menerima laporan atau pengaduan dari seorang tentang adanya tindak pidana; 2). Melakukan tindakan pertama pada saat di tempat kejadian; 3). Menyuruh berhenti seorang tersangka dan memeriksa tanda pengenal diri tersangka; 4). Melakukan penangkapan, penahanan, penggeledahan dan penyitaan; 5). Mengenai sidik jari dan memotret seseorang; 6). Memanggil orang untuk didengar dan diperiksa sebagai tersangka atau saksi; 7). Mendatangkan seorang ahli yang diperlukan dalam hubungannya dengan pemeriksaan perkara; 8). Mengadakan penghentian penyidikan; 9). Mengadakan tindakan lain menurut hukum yang bertanggung-jawab.

Setelah penyidikan selesai, maka kasus tersebut wajib dilimpahkan ke kejaksaan sebagai penuntut umum. Dalam hal penuntut umum berpendapat bahwa hasil penyidikan tersebut kurang lengkap, maka penuntut umum segera mengembalikan berkas perkara tersebut kepada penyidik disertai petunjuk untuk dilengkapi. Sedangkan bila dalam waktu 14 hari penuntut umum tidak mengembalikan berkas tersebut, maka penyidikan dianggap selesai.

Selanjutnya penuntut umumlah yang menentukan suatu perkara hasil penyidikan, apakah sudah lengkap atau tidak untuk dilimpahkan ke Pengadilan Negeri untuk diadili. Jika menurut pertimbangan penuntut umum suatu perkara tidak cukup bukti untuk diteruskan ke pengadilan ataukah perkara tersebut bukan merupakan delik, maka penuntut umum membuat suatu ketetapan mengenai hal itu (Pasal 140 ayat 2 butir b KUHAP). Penuntut umum juga memiliki kewenangn untuk menutup suatu perkara demi hukum (Pasal 140 ayat 2 butir a KUHAP).Penuntut umum selanjutnya membuat surat dakwaan berdasarkan hasil penyidikan.

Setelah hasil penyidikan selesai dan dituangkan dalam Berita Acara Pemeriksaan (BAP), maka hasil penyidikan tersebut diserahkan kepada Kejaksaan sebagai penuntut umum. Kejaksaan sebagai penuntut umum akan memberikan atau memasukkan pasal-pasal yang di langgar serta jenis tuntutan yang 
menyertainya, seperti: hukuman penjara atau hukuman badan, hukuman mati, denda dan sebagainya.

Terhadap suatu perkara telah dilakukan penuntutan, maka perkara tersebut selanjutnya diajukan kepengadilan untuk disidangkan (diperiksa, diadili dan diputus) oleh majelis hakim sesuai jadwal yang telah ditetapkan. Salah satu acara dalam persidangan suatu perkara adalah pembuktian (sesuai dengan sistem pembuktian yang diatur di dalam Pasal 183 KUHAP). Dalam kaitan ini hakim tidak boleh menjatuhkan pidana kepada seseorang kecuali didasarkan dengan sekurang-kurangnya dua alat bukti yang sah dan hakim memperoleh keyakinan bahwa suatu tindak pidana benar-benar terjadi dan bahwa terdakwa lah yang terbukti melakukannya.

Setelah majelis hakim menjatuhkan putusan kepada terpidana, maka kepada terpidana diberikan hak untuk menerima putusan tersebut atau melakukan perlawanan, atau menggunakan upaya hukum yang menjadi haknya paling lambat 14 hari sejak putusan ditetapkan hakim. Upaya hukum tersebut antara lain; mengajukan banding, kasasi atau peninjauan kembali. Sedangkan bila putusan tersebut telah memperoleh kekuatan hukum tetap, maka selanjutnya putusan tersebut harus dilaksanakan (atau di eksekusi) berdasarkan apa yang menjadi muatan (diktum) putusan hakim.

Pada tataran inilah kembali kita pertanyakan bagaimana pemahaman para hakim tentang asas, "Demi Keadilan Berdasarkan Ketuhanan Yang Maha Esa". Pertanyaan yang muncul adalah, mengapa bangsa yang mayoritas beragama Islam justru penduduknya, budayanya dan fenomena kehidupan yang setiap saat kita saksikan sangat banyak bertentangan dengan nilai-nilai agama Islam? Penyebabnya bermula dari sikap banyak kalangan yang masih selalu melihat manusia dari sisi fisik dengan pelekatan peran sains dan teknologi terlepas dari sisi non fisik dengan peran nilai-nilai agama. Selama manusia secara umum dan aparat penegak hukum secara khusus belum memahami hakekat dirinya dari sudut pandang agama (religi) maka selama itu pula kekeliruan dan penghancuran terhadap hidup dan kehidupan ini akan selalu terjadi. Apatah lagi bila manusia yang ada di permukaan bumi ini masih membanggakan kemampuan sains dan teknologi untuk menyelesaikan berbagai persoalan kehidupan manusia. Sains dan teknologi sejatinya tidak akan pernah dapat menyelesaikan berbagai persoalan hidup yang melingkupi kehidupan, bila sains dan teknologi itu lepas dari induk centrumnya (hakekat diri menurut agama). Termasuk hukum sebagai suatu produk ilmu pengetahuan.

Dalam bahasan Undang Undang Dasar 1945, pada Pasal 27 ayat (1) diatur bahwa: "Segala warga negara bersamaan kedudukannya di dalam hukum dan 
pemerintahan dan wajib menjunjung hukum dan pemerintahan itu dengan tidak ada kecualinya". Muatan pasal ini jelas memperlihatkan bahwa sebagai negara hukum, maka di Indonesia hukum lah yang tertinggi. Tidak ada satu pun elemen masyarakat,bangsa dan negara yang boleh mengesampingkan aturan hukum yang ada. Tidak ada satu pun orang di dalam negara ini yang kebal terhadap hukum. Bila terjadi sengketa yang tidak bisa diselesaikan secara damai, maka peradilan sebagai institusi terakhir yang diharapkan bisa menyelesaikan sengketa yang ada dengan menegakkan keadilan dan kebenaran sebagaimana mestinya.

\section{B. Memahami Prinsip Peradilan}

Menempatkan hakim sebagai terminal terakhir bagi para pencari keadilan dalam proses peradilan, berarti adanya kepercayaan warga masyarakat bahwa hakim dapat memberi keadilan dan dapat menjatuhkan putusan yang bersifat menyelesaikan perkara. Para pencari keadilan akan kecewa apabila putusan hakim tidak mencerminkan rasa keadilan serta kepastian hukum. Dengan putusannya hakim harus dapat mempertanggung-jawabkan kepada semua pihak, yaitu: kepada para pihak, masyarakat, pengadilan yang lebih tinggi dan ilmu pengetahuan hukum, dan terutama kepada Tuhan Yang Maha Esa.

Di dalam undang undang kekuasaan kehakimam (UU No. 48 Tahun 2009),pada bab dua tentang ASAS PENYELENGGARAAN KEKUASAAN KEHAKIMAN pada Pasal 2 (1) ditegaskan bahwa: Peradilan dilakukan "DEMI KEADILAN BERDASARKAN KETUHANAN YANG MAHA ESA". Pada ayat (2) dinyatakn bahwa: Peradilan negara menerapkan dan menegakkan hukum dan keadilan berdasarkan Pancasila. Selanjutya ayat (3) menegaskan bahwa: Semua peradilan di seluruh wilayah negara Republik Indonesia adalah peradilan negara yang diatur dengan undang-undang. Pada ayat (4) ditegaskan bahwa: Peradilan dilakukan dengan sederhana, cepat, dan biaya ringan.

Kemudian pada bagian penjelasan Pasal 2 Ayat (1) dinyatakan bahwa: Peradilang dilakukan "DEMI KEADILAN BERDASARKAN KETUHANAN YANG MAHA ESA" adalah sesuai dengan Pasal 29 Undang-Undang Dasar Negara Republik Indonesia Tahun 1945 yang menentukan bahwa negara berdasarkan atas Ketuhanan Yang Maha Esa dan negara menjamin kemerdekaan tiap-tiap penduduk untuk memeluk agamanya masing-masing dan untuk beribadat menurut agamanya dan kepercayaannya itu.

Selanjutnya bila kita telusuri Undang Undang Peradilan Umum UU No. 2 Tahun 1986, yang kemudian di revisi dengan UU No. 8 Tahun 2004 dan terakhir direvisi dengan UU No. 49 Tahun 2009 tentang Peradilan Umum. Tidak ada satu pun kalimat atau pasal atau ayat dalam ketiga undang-undang tersebut yang 
menindak-lanjuti atau membahas tentang prinsip peradilan yaitu: Demi Keadilan Berdasarkan Ketuhanan Yang Maha Esa. Secara tidak langsung yang bisa dikaitkan dengan prinsip tersebut adalah, Pasal 14 UU No. 2 Tahun 1986 tentang syarat untuk dapat diangkat menjadi Hakim Pengadilan Negeri yang salah satunya adalah, "bertaqwa kepada Tuhan Yang Maha Esa". Demikian juga Pasal 17 tentang sumpah atau janji sebagai hakim menurut agama dan kepercayaannya.

Dalam UU No. 8 Tahun 2004, pasal yang secara tidak langsung bisa dikaitkan dengan prinsip peradilan di atas adalah: Pasal 14 tentang syarat untuk dapat diangkat sebagai calon hakim, salah satunya adalah, "bertaqwa kepada Tuhan Yang Maha Esa. Juga Pasal 17 tentang sumpah dan janji sebelum memangku jabatan sebagai hakim, "Demi Allah saya bersumpah bahwa saya akan....”. Selanjutnya di dalam UU No. 49 Tahun 2009 pasal yang juga secara tidak langsung dapat dikaitkan dengan prinsip peradilan di atas adalah Pasal 13B ayat (1) Hakim harus memiliki integritas dan kepribadian tidak tercela, jujur, adil, profesional, bertaqwa dan berakhlak mulia, serta berpengalaman dibidang hukum. Selanjutnya pada Pasal 14, salah satu syarat untuk dapat diangkat sebagai hakim adalah, "bertaqwa kepada Tuhan Yang Maha Esa".

Pasal-pasal tersebut di atas tentu saja secara tidak langsung telah mengindikasikan bahwa hakim-hakim itu adalah orang-orang yang memiliki tingkat pengetahuan agama yang luas sehingga dipersyaratkan sebagai orangorang yang bertaqwa Kepada Tuhan Yang Maha Esa. Demikian juga di awal melaksanakan tugasnya sebagai hakim harus bersumpah atas nama Allah (Tuhan Yang Maha Esa). Dengan kapasitas itu maka seorang hakim tentu saja tidak susah atau tidak sulit untuk menerapkan prinsip peradilan, Demi Keadilan Berdasarkan Ketuhanan Yang Maha Esa, oleh karena mereka sudah dikategorikan sebagai orang-orang yang bertaqwa. Orang bertaqwa adalah orang yang kesehariannya senantiasa menjaga tutur kata dan sikapnya sesuai dengan perintah dan larangan Tuhan.

Berbeda dengan undang-undang di atas, maka bila kita telusuri Undang Undang Peradilan Agama (UU No. 7 Tahun 1989 yang kemudian di revisi dengan UU No. 3 Tahun 2006) prinsip tersebut ada di atur. Pada Pasal 57 ayat (1) Peradilan dilakukan DEMI KEADILAN BERDASARKAN KETUHANAN YANG MAHA ESA. Pada ayat (2) Tiap penetapan dan putusan dimulai dengan kalimat BISMILLAHIRRAHMANIRRAHIM diikuti dengan DEMI KEADILAN BERDASARKAN KETUHANAN YANG MAHA ESA. Pada ayat (3) Peradilan dilakukan dengan sederhana, cepat, dan biaya ringan.

Sejatinya pengaturan tersebut hanya penegasan lanjutan dari apa yang sudah di atur di dalam undang-undang kekuasaan kehakiman. Harapan kita 
sebenarnya adalah, undang-undang peradilan agama ini lebih luas mengatur prinsip peradilan, "Demi Keadilan Berdasarkan Ketuhanan Yang Maha Esa”, agar hakim-hakim peradilan agama dapat memiliki visi dan misi yang sama tentang bagaimana menerapkan prinsip tersebut di dalam segenap proses peradilan yang terjadi di pengadilan agama.

Demikian halnya dengan Undang-undang tentang Mahkamah Agung (UU No.14 Tahun 1985 yang kemudian di revisi dengan UU No. 5 Tahun 2004 dan terakhir di revisi dengan UU No. 3 Tahun 2009). Bila kita telusuri undang-undang tentang mahkamah agung ini juga tidak ditemukan kalimat dalam pasal atau ayat yang mengatur lebih lanjut tentang prinsip peradilan, "Demi Keadilan berdasarkan Ketuhanan Yang Maha Esa".

Urain-uraian yang secara tidak langsung bisa dikaitkan dengan prinsip peradilan tersebut di dalam undang-undang ini adalah, Pasal 7 (UU No. 14 Tahun 1985) bahwa, untuk dapat diangkat menjadi Hakim Agung seorang calon harus memenuhi syarat-syarat yang salah satunya adalah, "bertaqwa kepada Tuhan Yang Maha Esa". Demikian juga pasal 9 tentang sumpah atau janji menurut Agama atau Kepercayaannya.

Selanjutnya di dalam UU No. 5 Tahun 2004, juga tidak ada mengatur tentang prinsip peradilan di atas. Pasal yang bisa dikaitkan dengan prinsip peradilan di atas adalah Pasal 7 tentang syarat untuk diangkat menjadi hakim agung salah satunya adalah: "bertaqwa kepada Tuhan Yang Maha Esa". Demikian juga dengan Pasal 9 tentang sumpah pada ayat (2) bahwa, Sumpah atau janji hakim agung sebagaimana dimaksud pada ayat (1) berbunyi sebagai berikut: "Demi Allah saya bersumpah bahwa saya......".

Demikian juga revisi ketiga undang-undang Mahkamah Agung (UU No. 3 Tahun 2009). Kita lagi-lagi tidak menemukan penjabaran lebih lanjut tentang prinsip peradilan, "Demi Keadilan Berdasarkan Ketuhana Yang Maha Esa”. Pasal yang bisa dikaitkan dengan prinsip tersebut adalah: Pasal 7 tentang syarat untuk diangkat menjadi hakim agung salah satunya adalah, "bertaqwa kepada Tuhan Yang Maha Esa". Selanjutnya pada Pasal 9 ayat (1) tentang supah dan janji hakim agung, bahwa: "Demi Allah saya bersumpah bahwa saya.....". Sebagimana uraian di atas bahwa, pasal-pasal tersebut hanya bisa mengindikasikan bahwa hakimhakim termasuk hakim agung sebelum terpilih menjadi hakim adalah orang-orang pilihan termasuk orang-orang yang bertaqwa kepada Tuhan Yang Maha Esa sehingga harapan yang kita letakkan di pundaknya untuk mewujudkan peradilan yang berdasarkan prinsip, Demi Keadilan berdasarkan Ketuhanan Yang Maha Esa bisa terwujud di dalam setiap perkara yang ditanganinya. 
Sebagai sebuah harapan tentu sah-sah saja, namun apakah ada jaminan prinsip, Demi Keadilan Berdasarka Ketuhanan Yang Maha Esa dapat terwujud di dalam kenyataan, disitulah masalahnya. Undang-undang yang mengatur dan terkait dengan peradilan sebagaimana di uraian di atas tidak ada satu pun aturan yang memberikan penjabaran tentang apa yang di maksud dengan prinsip, Demi Keadilan Berdasarkan Ketuhanan Yang Maha Esa serta bagaimana prinsip tersebut di implementasikan. Oleh karena tidak adanya penjabaran lanjutan atau petunjuk teknis bagaimana hal itu dipahami dan diimplementasikan maka semuanya terpulang kepada hakim-hakim yang ada bagaimana dia memahami dan mengimplementasikan hal tersebut.

Hanya apakah itu mungkin? Oleh karena kredibilitas hakim dalam menyelesaikan perkara hingga kini banyak dipersoalkan oleh masyarakat. Masih terdapat indikasi korupsi, kolusi dan nepotisme, jual beli keadilan dan putusan sesuai selera dan besarnya bayaran kepada hakim serta adanya pengaruh dari pihak-pihak lain di luar institusi Mahkamah Agung. Tingkat ketidak-percayaan publik kepada hakim sudah parah yang paling tidak ditandai dengan keberanian masyarakat untuk mengamuk di ruangan sidang, mendemo pihak kepolisian yang melakukan penahanan dan yang lainnya. Untuk itu diperlukan adanya refleksi bagi para hakim untuk menata diri. Diperlukan upaya serius, massif dan berkesinambungan untuk mengembalikan citra para hakim agar lebih membela kepentingan rakyat. Untuk itu perlu dilakukan reformasi bagi para hakim, hakim harus dibersihkan dari pengaruh kepentingan internal dan eksternal dan dari sinilah penegakan hukum akan dimulai.

Seperti halnya pemilihan hakim-hakim agung untuk mengisi Mahkamah Agung yang dilakukan dengan fit and proper test oleh Dewan Perwakilan Rakyat (DPR) dirasakan masih belum dapat menghasilkan hakim agung yang baik, karena proses rekruitmen dengan cara tersebut sarat dengan kepentingan politik yang ikut mempengaruhinya ${ }^{11}$. Oleh karena itu untuk mewujudkan sistem peradilan yang baik perlu diwujudkan suatu sistem rekruitmen dan karier hakim yang baik. Peningkatan kemampuan penguasaan ilmu hukum, demikian juga pembinaan keterampilan teknis yang berkesinambungan. Pembinaan melalui jalur pendidikan dan pelatihan diamanatkan sebagai upaya peningkatan: 1). Sikap dan semangat pengabdian yang berorientasi pada kepentingan masyarakat, bangsa, negara dan tanah air; 2). Kompetensi teknis, manajerial, dan atau kepemimpinan; 3). Efisiensi, efektifitas, dan kualitas pelaksanaan tugas yang dilakukan dengan

\footnotetext{
${ }^{11}$ Lihat Akil Mochtar sebagai Hakim Konstitusi yang merupakan produk DPR yang berlatar belakang sebagai politisi. Ternyata meskipun sudah menjadi Hakim Mahkamah Konstitusi, akan tetapi kepentingan-kepentingan dan lobi-lobi politiknya tidak juga hilang.
} 
semangat kerjasama dan tanggung-jawab sesuai dengan lingkungan kerja organisasinya.

Sebagaimana telah diatur di dalam undang-undang kekuasaan kehakiman (UU No. 48 Tahun 2009) pada Pasal 2 ayat (1) bahwa: Peradilan dilakukan, Demi Keadilan Berdasarkan Ketuhanan Yang Maha Esa, kemudian pada bagian penjelasan hal tersebut dijelaskan bahwa peradilan dilakukan, Demi Keadilan Berdasarkan Ketuhanan Yang Maha Esa, adalah sesuai dengan Pasal 29 Undang Undang Dasar Negara Republik Indonesia Tahun 1945 yang menentukan: 1). Negara berdasarkan atas Ketuhanan Yang Maha Esa; 2). Negara menjamin kemerdekaan tiap-tiap penduduk untuk memeluk agama masing-masing dan untuk beribadat menurut agamanya dan kepercayaannya itu.

Penelusuran penelitian ini melalui wawancara dan diskusi dengan hakimhakim dari berbagai jenis dan tingkatan pengadilan termasuk penasehat hukum semakin memperjelas kesimpulan di atas. Hakim-hakim umumnya tidak memahami secara baik prinsip peradilan tersebut. Hakim-hakim tidak memiliki visi dan misi yang sama tentang prinsip peradilan tersebut. Mereka hanya memahami secara sederhana dan dangkal prinsip tersebut bahwa, putusan hakim harus dapat dipertanggung-jawabkan dunia akhirat. Irah-irah putusan, "Demi Keadilan Berdasarkan Ketuhanan Yang Maha Esa", yaitu suatu prinsip hukum dalam peradilan yang menjadi tuntunan dan menjadi hal yang mendasari untuk memberikan putusan karena itu hakim harus mandiri atau independen dengan tidak melaksanakan tugas karena perintah dan intervensi tapi karena semata-mata untuk dapat mempertanggung-jawabkan putusannya kepada Tuhan.

Konsekwensi jika irah-irah putusan tersebut tidak ada, maka berdasarkan undang-undang putusan tersebut adalah batal demi hukum. Untuk itu irah-irah putusan, "Demi Keadilan Berdasarkan Ketuhanan Yang Maha Esa", dapat diterapkan berdasarkan esensi dari tiap-tiap hakim, dan itu wajib diterapkan dalam memutuskan suatu perkara karena jika tidak berdasarkan pada irah-irah tersebut, maka putusan yang telah dijatuhkan seorang hakim atau suatu majelis hakim konsekwensinya adalah putusan menjadi batal demi hukum.

Bagaimana menilai atau mengukur bahwa proses peradilan dari aspek pemeriksaan dan putusan sudah berdasarkan pada irah-irah putusan, "Demi Keadilan Berdasarkan Ketuhanan Yang Maha Esa”. Mengukur suatu putusan sudah berdasarkan pada irah-irah putusan, "Demi Keadilan Berdasarkan Ketuhanan Yang Maha Esa”, yaitu berdasarkan beberapa pertimbangan yaitu: a. Mempertimbangkan suatu perkara yang ditinjau dari aspek sosiologis dan filosofis dengan melihat adat atau norma-norma yang berkembangan dalam masyarakat. b. Mempertimbangkan aspek hukum berdasarkan teori dan secara normatif yaitu 
dalam memutuskan suatu perkara harus juga didasarkan pada ketentuan hukum yang berlaku dan teori-teori hukum. c. Keyakinan hakim yang didasari dengan perasaan untuk berusaha mencapai keadilan. d. Melihat duduk perkara kemudian menerapkan hukum. e. Melihat tujuan hukum baik karena kepastian hukumnya, kemanfaatannya, dan karena keadilan.

Sebagaimana dikemukakan sebelumnya, maka hakim yang lain memahami makna dari prinsip peradilan, "Demi Keadilan Berdasarkan Ketuhanan Yang Maha Esa", adalah putusan yang dibuat oleh seorang hakim atau oleh majelis hakim maka selain dapat dipertanggung-jawabkan di dunia melalui tata peraturan perundang-undangan yang ada, baik yang berkaitan dengan para pihak yang terkait dengan suatu perkara, maka juga dapat dipertanggung-jawabkan kepada masyarakat serta kepada lembaga peradilan di atasnya. Hal yang lebih penting dari itu bahwa putusan tersebut harus dapat dipertanggung-jawabkan di akhirat dihadapan Allah swt. Dalam tataran duniawi saja bila putusan tersebut tidak mencantumkan iarah-irah putusan, maka putusan tersebut menjadi batal demi hukum dan akibat hukumnya, putusan tersebut tidak dapat dilaksanakan. Maka bagaimana putusan tersebut dihadapan Allah swt.

Hakim lainnya memahami prinsip peradilan, "Demi Keadilan Berdasarkan Ketuhanan Yang Maha Esa", bahwa hakim di dalam memeriksa suatu perkara hingga menjatuhkan putusan tidak boleh ada intervensi dari pihak manapun. Demikian juga seorang hakim tidak boleh takut kepada siapapun. Hakim hanya takut dan bertanggung-jawab sepenuhnya kepada Tuhan Yang Maha Esa. Ada pun asas keadilan yang tumbuh di tengah-tengah masyarakat hakim harus menjadikannya sumber hukum atau pertimbangan oleh karena hakim itu bukan semata-mata corong undang-undang. Demikian juga harus memperhatikan betul asas manfaat dari suatu putusan serta asas kepatuhan terhadap suatu putusan.

Demikian juga dengan Hakim berikutnya, menurut beliau makna atau pesan yang terkandung di dalam prinsip peradilan, "Demi Keadilan Berdasarkan Ketuhanan Yang Maha Esa", adalah setiap putusan hakim harus dapat di pertanggung-jawabkan baik di dunia maupun di akhirat kelak. Hakim adalah wakil Tuhan di dunia, tidak berlebihan bila dikatakan bahwa selain Tuhan yang punya otoritas untuk menentukan hidup matinya seseorang, maka yang kedua adalah para hakim, ketika menjatuhkan hukuman mati terhadap seorang terdakwa. Untuk itu hakim di dalam menjalankan tugas dan fungsinya tidak boleh bermainmain atau melakukan tindakan-tindakan yang bertentangan dengan tugas dan fungsinya, termasuk bertentangan dengan kode etik hakim. Misalnya putusan dibuat berdasarkan pesanan atau besarnya uang sogokan yang diberikan oleh pihak-pihak yang berperkara. Sekali seorang hakim melakukan hal tersebut, maka 
selamanya hakim tersebut tidak lagi layak untuk bekerja atau diberi tugas dan jabatan sebagai hakim, apalagi untuk diberi tugas untuk menangani suatu perkara.

Sedangkan pendapat dari seorang Advokat, cukup mengagetkan penelita oleh karena pandangan beliau berbeda dengan pandangan-pandangan yang dikemukakan sebelumnya. Menurut beliau penerapan prinsip peradilan, "Demi Keadilan Berdasarkan Ketuhanan Yang Maha Esa”, itu mustahil untuk dapat diterapkan oleh karena sistem hukum serta sistem peradilan yang kita anut bukan lah sistem hukum dan sistem peradilan yang didasarkan kepada hukum-hukum agama. Sistem hukum dan sistem peradilan kita adalah sistem hukum dan sistem peradilan sekuler. Jadi jika asas tersebut hendak diterapkan maka terlebih dahulu sistem hukum dan sistem peradilan kita harus dirobah agar sesuai dengan sistem hukum (Islam).

Tugas sebagai hakim memang tidak mudah alias berat. Dalam pandangan ajaran Islam seorang hakim itu, satu kakinya ada di neraka dan satu kakinya ada di surga. Bagimana tidak hakim di dalam menjatuhkan putusan adalah atas nama Tuhan Yang Maha Esa. Kesalahan penjatuhan hukuman adalah sebuah kesalahan besar yang pertanggung-jawabannya adalah kepada Tauhan Yang Maha Esa. Dengan demikian hakim sejatinya bukanlah manusia biasa, seperti manusia pada umumnya. Hakim sejatinya dapat disejajarkan dengan para Nabi dan Rasul karena pada masanya para Nabi dan Rasul ini lah yang bertindak selaku hakim di dalam menyelesaikan perkara-perkara masyarakat baik dalam ranah perdata maupun dalam ranah pidana.

\section{Memaknai Prinsip Peradilan}

Problematika yang melekat pada sisi kemanusiaan aparat penegak hukum adalah mereka tidak memahami diri yang sebenarnya diri pada dirinya, diri yang beragama. Substansi diri yang menyebabkan seseorang bisa berjalan, bisa lapar dan kenyang, bisa berfikir dan bisa hidup atau mati. Substansi diri itulah yang jika tidak ada lagi maka seseorang di sebut telah mati atau meninggal dunia dan tidak bisa berbuat apa-apa lagi. Diri yang sebenarnya diri yang pada akhirnya nanti menghadap dan bertanggung-jawab kepada Tuhan Yang Maha Esa di alam akhirat. Inilah yang selalu kita dengar dari ulama-ulama kita bahwa: Allah tidak melihat pada rupamu dan amalmu, hanya Allah melihat pada hatimu dan niat kamu. Allah hanya melihat pada entitas diri tersebut yang menjadi pusat proses berfikir dan pusat pengendali kedirian manusia. Untuk itu ukuran normatif yang digunakan untuk nilai norma sosial-budaya yang dapat dipandang ma'ruf adalah nilai-nilai kebenaran Ilahiyah (al haq) sebagaimana telah diajarkan di dalam agama (Islam). 
Selama aparat penegak hukum masih belum memahami diri dan kediriannya dari sudut pandang spiritualitas (Agama Islam) maka kita jangan pernah berharap untuk lahirnya peraturan perundang-undangan yang berkeadilan. Demikian juga untuk tegaknya hukum sesuai dengan tujuan hukum. Aparat penegak hukum yang tidak memahami eksistensi dirinya dari sisi spiritualitas maka hidup kesehariannya akan senantiasa didorong dan dilingkupi oleh "hawa nafsu setan" dan inilah yang membuat rusaknya moralitas aparat penegak hukum. Sebaliknya dengan memahami nilai-nilai spiritualitas (Agama Islam) maka hidup keseharian aparat penegak hukum akan senantiasa dilingkupi oleh sifat-sifat: siddiq, amanah, tabligh dan fatonah. Aparat penegak hukum yang benar-benar bisa diharapkan untuk menegakkan hukum berdasarkan prinsip, "Demi Keadilan Berdasarkan KeTuhana Yang Maha Esa”.

Dengan demikian ke depan peraturan perundang-undangan tentang peradilan, mulai dari pengadilan negeri, pengadilan tinggi hingga mahkamah agung (termasuk peradilan agama), perlu direvisi. Perlunya revisi tersebut didasarkan pada pertimbangan urain di atas, tentang tidak cukupnya uraian atau penjelasan apa sesungguhnya yang dimaksud dengan asas, Demi Keadilan Berdasarkan Ketuhanan Yang Maha Esa. Termasuk perlunya aturan tentang petunjuk teknis dalam penerapan asas tersebut dalam segenap proses peradilan serta tingkah laku hakim.

Pada sisi inilah kita temukan kelemahan institusi hukum. Kelemahan dan ketidak mampuan hukum untuk ditegakkan oleh manusia-manusia yang melingkupinya. Hal tersebut berhadapan dengan sisi negatif kedirian manusia yang juga hingga kini tidak dipahami sumber penyebabnya yang merupakan area “ajaran agama”. Sisi negatif kedirian manusia yang senantiasa mengajak kepada perbuatan-perbuatan negatif berupa perbuatan melanggar hukum. Hal inilah sejatinya yang disebut entitas kafir yang senantiasa mengajak kepada pemikiran dan perilaku jahat (melanggar peraturan perundang-undangan dan sumpah jabatan).

Semakin jelas bahwa pada tataran inilah kita lihat betapa pentingnya pemahaman hakim terhadap prinsip peradilan, "Demi Keadilan Berdasarkan Ketuhanan Yang Maha Esa". Prinsip tersebut tentu saja akan menjadi pijakan dan penuntun kerja serta bentuk pertanggung-jawaban putusan tidak hanya pada tataran duniawi akan tetapi juga tanggung-jawab kepada Tuhan Yang Maha Esa. Hanya saja mungkin kah itu dapat terwujud atau terimplementasikan? Sepertinya sulit oleh karena pembahasan di atas telah menunjukkan bahwa aparat penegak hukum yang ada, khususnya para hakim-hakim, hanya menempatkan prinsip 
peradilan tersebut pada sesi akhir setelah putusan dijatuhkan, bahwa putusan itu harus dapat dipertanggung-jawabkan dunia akhirat.

Bagaimana mungkin sebuah putusan hakim dapat dipertanggung-jawabkan kepada Tuhan Yang Maha Esa, bila proses-proses awal yang menyertai suatu perkara hingga di putus tidak diasarkan kepada prinsip-prinsip "Ketuhanan" sebagaimana diatur di dalam hukum-hukum agama (Islam). Misalnya hakimhakim ketika masuk ruangan sidang, membuka sidang hingga menutup sidang seharusnya mengucapkan salam (Assalamu Alaikum warahmatullahi wabarakatuh). Kemudian terdakwa dan para saksi-saksi seharusnya ditempatkan dan diperlakukan sebagai manusia layaknya sebagai hamba Tuhan. Bahkan sejatinya seorang hakim patut menggunakan pandangan syari'at Islam tentang kasus yang ditanganinya untuk dapat dibandingkan dengan hukum-hukum negara yang ada (meskipun itu dilakukan secara pribadi di dalam analisis hukumnya dan tidak dimunculkan di dalam putusan).

Apa yang bisa kita harapkan kepada segenap aparat penegak hukum yang ada (hakim-hakim), bila mereka hanya memahami prinsip peradilan, "Demi Keadilan Berdasarkan Ketuhanan Yang Maha Esa", bahwa setiap putusan yang dijatuhkan harus dapat dipertanggung-jawabkan dunia akhirat. Kalau pertanggung-jawaban itu menyebabkan sang penegak hukum (hakim-hakim) masuk sorga tentu bagus. Akan tetapi bila pertanggung-jawaban itu menyebabkan sang hakim mendekam di neraka, bagaimana?

Penulis mungkin tidak berlebihan bila menyatakan bahwa kita semua juga sangat paham dan mengerti bahwa dalam hal-hal tertentu manusia memiliki berbagai keterbatasan dalam menjalani hidup dan kehidupan ini, termasuk di dalamnya adalah kemampuan untuk menyelesaikan masalah yang dihadapinya. Dan ketika masalah itu datang dan kita tidak mampu lagi untuk menanganinya, maka disitulah kita harus memasrahkan diri secara totalitas kepada kekuasaan Tuhan Yang Maha Esa untuk memberikan pertolongannya. Inilah salah satu wujud ketinggian keimanan dan ketaqwaan kita kepada Tuhan Yang Maha Esa. Sejatinya seluruh anak-anak bangsa ini harus memahami bahwa tidak ada satu pun aspek dalam hidup dan kehidupan kita yang bisa lepas dari campur tangan Tuhan. Hidup mati kita adalah di tangan-Nya. Bagaimana mungkin ada hal yang lepas dari campur tangan-Nya bila kita sudah pahami bahwa kita semua berasal darinya dan akan kembali kepada-Nya.

Allah SWT telah mengingatkan di dalam Surat Al-Hadiid ayat (25) bahwa: Sesungguhnya Kami telah mengutus Rasul-rasul Kami dengan membawa buktibukti yang nyata dan telah Kami turunkan bersama mereka Al kitab dan neraca (keadilan) supaya manusia dapat melaksanakan keadilan dan Kami ciptakan besi 
yang padanya terdapat kekuatan yang hebat dan berbagai manfaat bagi manusia, (supaya mereka mempergunakan besi itu) dan supaya Allah mengetahui siapa yang menolong (agama) Nya dan rasul-rasul-Nya padahal Allah tidak dilihatnya. Sesungguhnya Allah Maha kuat lagi Maha Perkasa.

Sangat jelas bisa kita pahami ayat-ayat di atas bahwa umat manusia adalah ciptaan Allah SWT. Menyertai penciptaan tersebut Allah SWT juga menurunkan al-qur'an yang akan menjadi penuntun dan tuntunan di dalam menjalani hidup dan kehidupan ini. Dengan demikian tidk ada alasan untuk menempatkan nilai-nilai ajaran agama sebagai penghuni bagian belakang kehidupan dan hanya dibutuhkan untuk kepentingan ibadah-ibadah ritual semata. Dalam kaitan menempatkan peran agama (Tuhan Yang Maha Kuasa) dalam ruang individu dan ruang publik juga kita masih memiliki sederet permasalahan. Salah satu permasalahan yang dimaksud adalah atmosfir keberagamaan masyarakat kita masih dominan aspek syar'inya. Bahkan aspek syari'at itu pun belum dipahami dengan baik sehingga berimplikasi pada sisi pengamalannya. Malahan dalam beberapa hal pemahaman syari'at itu terdapat kekeliruan. Pada tataran inilah urgennya aparat penegak hukum memahami hakekat dirinya dari sudut pandang agama (religi), agar bisa menjadi penegak hukum yang menegakkan prinsip peradilan,

Allah SWT di dalam Al-Qur'an telah mengingatkan dan menegaskan kepada kita pada Surat As-Sajadah ayat (9) bahwa: Kemudian Dia menyempurnakan kejadian manusia dan meniupkan ke dalamnya roh (ciptaan)Nya dan Dia menjadikan bagi kamu pendengaran, penglihatan dan hati, (tetapi) kamu sedikit sekali bersyukur.

Proses peradilan di Indonesia di tuntut senantiasa menjunjung tinggi asasasas peradilan. Demikian halnya dengan asas "Demi Keadilan Berdasarkan Ke Tuhanan Yang Maha Esa”. Agar segenap aparat penegak hukum (Polisi sebagai penyidik, Jaksa sebagai penuntut umum, Hakim sebagai pemutus dan Penasehat Hukum sebagai pembela tersangka) dapat mengimplementasikan nilai-nilai yang terkandung dalam asas tersebut, maka tentu saja harus di awali dengan adanya pemahaman keagamaan yang baik dan benar. Baik dan benar dalam arti sesuai dengan tuntunan ajaran agama yang ada. Demikian juga diperlukan pengaturan lanjutan dalam peraturan perundang-undangan apa yang dimaksud dengan asas, Demi Keadikan Berdasarkan Ketuhanan Yang Maha Esa, termasuk adanya tuntunan bagaimana cara mengimplementasikan asas tersebut dalam realitas penanganan suatu masalah hukum. Bila pengertian dan tuntunan tentang asas tersebut tidak ada, maka asas tersebut hanya akan menjadi hiasan di atas kertas peraturan perundang-undangan dan hiasan bibir segenap aparat penegak 
hukum yang tidak akan pernah bisa di implementasikan di dalam realitas dunia peradilan Indonesia ${ }^{12}$.

Jadi jelas sudah bahwa akar dari segala permasalahan dalam hidup dan kehidupan ini adalah faktor manusia. Inilah wajah diameteral manusia yang bersifat antinomi. Di satu sisi, manusia dengan kecerdasan akalnya mampu menciptakan sains dan teknologi untuk meningkatkan sarana dan prasarana kehidupan untuk kesenangan dan kesejahteraan manusia. Akan tetapi di sisi lain dengan hawa nafsunya, manusia mampun menghancurkan segala tatanan peradaban yang telah diciptakannya. Menginjak-injak kembali aturan hukum yang telah dibuatnya.

Dalam menjalani hidup dan kehidupan ini kita tidak sepatutnya hanya menggunakan "rasa akademik" (sains dan teknologi) karena telah terbukti memiliki keterbatasan, akan tetapi harus menggunakan "rasa spiritual" yang tidak memiliki keterbatasan. Dengan demikian rasa akademik dan rasa spiritualitas harus digunakan secara sinergis untuk menyelesaikan berbagai persoalan yang melingkupi institusi hukum kita termasuk yang mengendap dalam diri kedirian manusia dan masyarakat. Dalam sepektrum agama tentu saja agama yang mengIndonesia, bukan Indonesia yang beragama.

Upaya untuk menerapkan prinsip tersebut dalam semua proses peradilan ternyata tidak lah semudah menyebutkan prinsip tersebut. Sebagaimana pembahasan di atas, diperlukan dekonstruksi pemahaman keagamaan pada segenap aparat penegak hukum yang ada (khususnya hakim-hakim). Pemahaman agama yang rendah apalagi keliru tentu saja tidak bisa diharapkan untuk mendukung penerapan prinsip peradilan, Demi Keadilan Berdasarkan KeTuhanan Yang Maha Esa". Beberapa asek dasar kehidupan beragama yang harus dipahami dengan baik adalah: memahami hakekat diri, memahami hakekat Tuhan, memahami hakekat Rasulullah dan memahami hakekat Baitullah.

\footnotetext{
${ }^{12}$ Sukarno Aburaera, Kekuasaan Kehakiman Indonesia, (Makassar: Arus Timur, 2012) h. 9-10 menyatakan bahwa: Dasar peradilan ini bisa saja hanya dimaknai hanya sebagai simbol putusan dalam memenuhi standar formal putusan atau betul-betul dihayati sebagai perilaku perdilan. Jika dasar peradilan ini hanya dipahami sebgai simbol dalam memenuhi standar formal putusan sebagai landasan eksekutorial dan formal sahnya putusan maka jangan pernah mengharapkan putusan hakim mengandung nilai-nilai keadilan dan jangan pernah mengharapkan putusan hakim dapat dipertanggung-jawabkan pada Tuhan, masyarakat, hukum dan untuk dirinya sendiri.
} 


\section{PENUTUP}

Proses penegakan hukum melalui peradilan di Indonesia berdasarkan Undang Undang tentang Kekuasaan Kehakiman (UU No. 48 Tahun 2009) dilaksanakan berdasarkan prinsip, "Demi Keadilan Berdasarkan Ketuhanan Yang Maha Esa". Hanya sayangnya, makna dari prinsip tersebut tidak diatur lebih lanjut. Akibat dari tidak jelasnya peraturan perundang-undangan tentang prinsip peradilan dilaksanakan berdasarkan, "Demi Keadilan Berdasarkan Ketuhanan Yang Maha Esa”, maka hakim-hakim yang menjadi tulang punggung penegakan hukum menjadi bias. Hakim-hakim tidak memiliki pegangan yang sama di dalam memahami prinsip tersebut. Pemahaman dan penerapan prinsip tersebut hanya dipahami secara general bahwa perkara yang ditanganinya harus dapat diperatanggung-jawabkan kehadapan Tuhan Yang Maha Esa.

Sebagai akibatnya hakim-hakim lembaga peradilan yang ada, baik dalam jajaran peradilan umum (Pengadilan Negeri, Pengadilan Tinggi hingga Mahkamah Agung), peradilan agama, peradilan tata usaha negara menghadapi kesulitan di dalam menerapkan prinsip tersebut. Kesulitan pertama adalah tidak adanya tuntunan teknis bagaimana menerapkan prinsip tersebut di dalam proses peradilan yang di tanganinya. Kedua, hakim-hakim tidak memiliki standar pemahaman agama yang sama. Hanya saja kita masih dapat bersyukur oleh karena faktor pendukung masih ada yaitu, hakim-hakim kita adalah umat beragama yang menjunjung tinggi nilai-nilai ajaran agama yang di anutnya, meskipun pada diri hakim-hakim itu dari sisi keberagamaan juga ternyata harus melakukan dekonstruksi disebabkan masih adanya kesalahan atau kekeliruan di dalam memahami hakekat diri, hakekat agama terutama sekali yang berkaitan dengan hakekat, "Tuhan". 


\section{DAFTAR PUSTAKA}

Achmad Ali, 1996. Menguak Tabir Hukum (Suatu Kajian Filosofis dan Sosiologis), Chandra Pratama, Jakarta.

1998. Menjelajahi Kajian Empiris Terhadap Hukum, PT. Yarsif Watamponen, Jakarta.

---------- 2009. Menguak Teori Hukum dan Teori Peradilan, Kencana Perdana Media, Jakarta.

Ahkam Jayadi, 2009. Hukum dan Keadilan Menguak Kewenangan Penegak Hukum dalam Penahanan dan Penangguhan Penahanan, Kota Kembang, Yogyakarta.

Allamah M.H. Thabathaba'i, 1997. Mengungkap Rahasia Al-Quran, Mizan, Bandung.

Ade Maman Suherman, 2007. Pengantar Perbandingan Sistem Hukum, PT. Raja Grafindo Persana, Jakarta.

Anton F. Susanto, 2010. Ilmu Hukum Non Sistematik, Fondasi Filsafat Pengembangan Ilmu Hukum Indonesia, Genta Publishing, Yogyakarta.

Artidjo Alkostar dan M. Sholeh Amin (editor), 1986. Pembangunan Hukum dalam Perspektif Politik Hukum Nasional, LBH dan Rajawali Pers, Jakarta.

Bachran Mustafa, 2003. Sistem Hukum Indonesia Terpadu, PT. Citra Aditya Bakti, Bandung.

Bustanuddin Agus, 2006. Agama Dalam Kehidupan Manusia, PT. Raja Grafindo Persada, Jakarta.

Daud Ali, M, dkk, 1988. Islam Untuk Disiplin Ilmu Hukum, Sosial dan Politik, Bulan Bintang, Jakarta.

Edy Suandi Hamid dan Muhammad Sayuti (penyunting), 1999. Menyingkap Korupsi, Kolusi dan Nepotisme di Indonesia, Aditya Media, Yogyakarta.

Friedman, Lawrence M, 1975. The Legal System: A Social Science Perspective, Russel Sage Foundation, New York.

Hussein Nasr, S, 1981. Islam Dalam Cita dan Fakta, Leppenas, Jakarta.

Jonedi Efendi, 2010. Mafia Hukum, Prestasi Pustaka, Jakarta.

Kelmen, HC. 1966. Complience, Identification, and Internalization, Three Processes of Attitude Change, dalam H. Prosharly and B. Seidelerd (ed), 
Basic Studies in Studies in Social Psychology, New York, Halt, Rhinehart \& Winston.

Mahfud, Moh MD, 2001. Politik Hukum di Indonesia, PT. Pustaka LP3ES Indonesia, Jakarta.

Nasikun, 2011. Sistem Sosial Indonesia, Jakarta: PT. Raja Grafindi Persada.

Otje Salman dan Anthon F. Susanto, 2009. Teori Hukum, Mengingat, Menyimpulkan, dan Membuka Kembali, PT. Refika Aditama, Bandung.

Purnadi Purbacaraka dan Soerjono Soekanto, 1986. Perihal Kaedah Hukum, Alumni, Bandung.

Philipe Nonet dan Philip Selznick, 2008. Law and Society in Transition, Toward Respons Law, (terjemahan: Raisul M), Nusa Media, Jakarta.

Roucek, Joseph S, 1951. Social Control, Doan Nostrand Company, Inc, London.

Ronny Rahman Nitibaskara, Tb, 2007. Tegakkan Hukum Gunakan Hukum, Penerbit Buku Kompas, Jakarta.

Raana Bokhari dan Mohammad Seddon, 2010. Ensiklopedia Islam, Erlangga, Jakarta.

Satjipto Rahardjo, 1986. Hukum dan Masyarakat, Angkasa, Bandung.

1987. Permasalahan Hukum di Indonesia, Alumni, Bandung.

2006. Membedah Hukum Progresif, Penerbit Buku Kompas, Jakarta.

---------- 2009. Hukum dan Perubahan Sosial, Suatu Tinjauan Teoritis Serta Pengalaman-Pengalaman di Indonesia, Genta Publishing, Yogyakarta.

Soerjono Soekanto, 1985. Evektivikasi Hukum dan Peranan Sanksi, CV. Remadja Karya, Bandung. 1993. Faktor-faktor Yang Mempengaruhi Penegakan Hukum, PT. Raja Grafindo Persada, Jakarta.

dkk, 1986. Perspektif Politik Hukum Nasional, LBH dan Rajawali Press, Jakarta.

Sudikono Mertokusumo, 1986. Mengenal Hukum, Liberty, Yogyakarta.

Sutandyo Wignjosoebroto, 2007. Hukum Dalam Masyarakat (Perkembangan dan Masalah, Sebuah Pengantar ke Arah Kajian Sosiologi Hukum, Fakultas Ilmu Sosial dan Ilmu Politik Universitas Airlangga, Surabaya. 